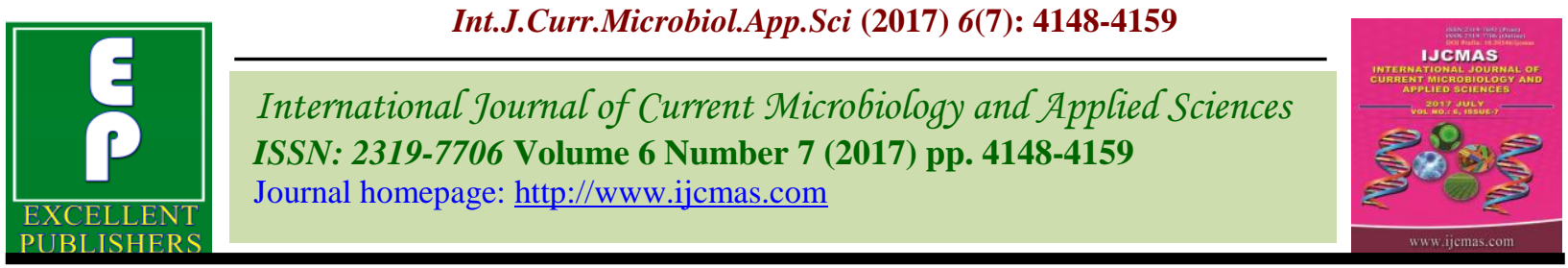

Original Research Article https://doi.org/10.20546/ijcmas.2017.607.430

\title{
Genotype Environment Interaction for Sugar-Related Traits in Sugarcane Mapping Population
}

\author{
Sujeet Pratap Singh ${ }^{*}$, R.K. Singh ${ }^{1}$, A. Nigam $^{2}$ and B.L. Sharma ${ }^{3}$ \\ ${ }^{1}$ Centre for Sugarcane Biotechnology, Sugarcane Research Institute, (U.P. Council of Sugarcane \\ Research), Shahjahanpur-242 001, U.P., India \\ ${ }^{2}$ School of Sciences, IGNOU, New Delhi-110 068, India \\ ${ }^{3}$ U.P. Council of Sugarcane Research, Shahjahanpur, U.P., India \\ *Corresponding author
}

A B S T R A C T

Keywords

Genotype $\times$ environment interaction, Regression coefficient, Stability, sugarcane, Yieldrelated traits.

Article Info

Accepted:

29 June 2017

Available Online:

10 July 2017
Genotype $\times$ environment $(G \times E)$ interaction plays a key role for better genetic improvement and identifies high yielding and stable cultivars under varying environmental conditions. Genetically stable traits play a key role in sugarcane breeding for improvement in sugarcane and sugar productivity. Present finding elucidates the relative magnitude of $\mathrm{G}$ $\times \mathrm{E}$ interaction effects and evaluating phenotypic stability of 226 segregating genotypes for sugar and yield-related traits and for their regression coefficient (bi) and population mean $(\mathrm{X})$ over the locations. $\mathrm{G} \times \mathrm{E}$ interaction was found significant for cane yield, indicating that the cane yield was highly influenced by the environment. Out of 226 progenies studied, 19 genotypes were found stable for sugar yield-related traits. Seventy genotypes were found stable for quality traits across both the environments, indicating the promising nature of these genotypes. This study indicates that maximum progenies are influenced by $\mathrm{G} \times \mathrm{E}$ interactions and minimum genotypes are stable across both environments for all traits. These findings would be informative for the selection of elite and stable genotypes within the single environment as well across the environments, to achieve the higher cane yield as well as other economic traits. Hence, $\mathrm{G} \times \mathrm{E}$ interaction could increase the efficiency of selection of stable genotypes for different agro-climatic regions.

\section{Introduction}

Sugar industry is the most significant agrobased organized industry of the world. Sugarcane (Saccharum spp. L.) is a one of the agro-industrial crop of India. It is widely grown primarily for sugar production worldwide in tropical and subtropical regions. Genotype $\times$ environment interaction is an important issue facing plant breeders. Better understanding of genotype-by-environment $(\mathrm{G} \times \mathrm{E})$ interactions is expected to provide a solid foundation for genetic improvement of crop productivity. To overcome this problem, huge trials have to be conducted across years and environments to identify the most suitable genotypes. The productivity of sugarcane clones varies from one location to another, indicating the presence of an environment effect. The importance of $\mathrm{G} \times \mathrm{E}$ interaction is a widely recognized phenomenon in sugarcane clonal selection trials (Jackson and Hogarth 1992; Kimbeng et al., 2002; Tiawari et al., 2011). Sugarcane productivity is a 
quantitative (polygenic) character and generally influenced by environmental variation, the productivity is being governed by stalk length, stalk girth, number of millable cane, (Hoarau et al., 2001; Aitken et al., 2006; Singh et al., 2013). An ideal variety is one that has high mean yield but a low degree of fluctuation in performance when grown over diverse environment.

Environmental effects on sugarcane yields may be due to differing nutrient deficiencies (Anderson et al., 1995), disease pressures (Magarey and Mewing 1994) or climatic differences between locations. Genotypes are influenced by climate, soil type, day length and controllable variables such as fertilization, sowing dates and harvesting methods. Beside this, the environment containing inter and intra-season fluctuation, fluctuation in quantity and distribution of rainfall and temperature are effect the sugar cane productivity. The performance of genotypes in favorable environments does not indicate their adaptability and stability (Khan et al., 2013).

Sugarcane productivity along with their quality is most important traits of sugarcane, which is more stable across the environments. The stable appropriate genotypes should be well adopted in all environments. Genotype $\times$ environment interaction is an important factor for better genetic improvement to identify high yielding and stable cultivars with high mean value that are more adapted to regional parts of the sugar industry (Tahir et al., 2013). Importance of genotype environment interaction is well established in the field of plant breeding. The objective of this experiment was to determine the relative magnitude of $\mathrm{G} \times \mathrm{E}$ interaction effects and to evaluate phenotypic stability among 226 progenies derived from UP $9530 \times$ Co 86011 in terms of regression coefficient (bi) and population mean $(\overline{\mathrm{X}})$ over both locations.

\section{Materials and Methods}

This experiment was laid out at Sugarcane Research Institute, Shahjahanpur (UP), Sugarcane Research Centre, Muzaffarnagar (U.P.) farm during 2011-12. Two hundred twenty six segregating population were evaluated from the bi-parental cross of UP $9530 \times$ Co 86011 . This population was planted at both locations for $G \times E$ in randomized block design with three replications. The basic plot of each progeny was $0.70 \times 0.90$ square meters and the row were spaced $0.90 \mathrm{~m}$ apart with two eye buds and treated set. The geographical distribution of Sugarcane Research Institute (SRI), Shahjahanpur having Longitude: $79^{\circ} 57^{\prime} \mathrm{E}$, latitude: $27^{0} 54^{\prime} \mathrm{N}$ and Muzaffarnagar having Longitude: $77^{\circ} 44^{\prime} \mathrm{E}$ and latitude: $29^{\circ} 28^{\prime} \mathrm{N}$ (Table 1 and Fig. 1). Fertilizers were applied as per recommended doses and standard agronomical practices were used.

\section{Phenotyping}

Phenotyping of the 226 segregating population for the sugar-related traits were concluded in first clonal generation $\left(\mathrm{C}_{1}\right)$. The sugar yield-related traits viz; stalk weight, stalk diameter, shoot count, number of millable cane, number of internodes, length of internodes, number of green leaf, leaf length, yield and H.R. brix were determined time to time for all progenies including both parents like UP 9530 and Co 86011. All the data were evaluated at Shahjahanpur and Muzaffarnagar location. The shoot count (SCNT), number of millable cane (NMC) was counted for the each plot of progeny at 120 and 360 days after planting (DAP) respectively. H.R. brix (HBR) was recorded with digital hand-held refractometer in standing crop of each replication during in October. The data of stalk length (SL) and stalks diameter (SD) was observed in centimeter $(\mathrm{cm})$ at 360 and 300 DAP, respectively. Number of green 
leaves (NGL) was counted for healthy selected stalk of each replicates at 300 DAP. Leave length (LL-cm) was observed of the third visible leaf of the top stalk at 300 DAP. Internode length (INTL) was recorded for each progenies by using scale in centimeter. INTL was measured at mid-length of the stalk. Three cane stalks from each plot were harvested to record per stalk weight (SW) data in gram at 360 DAP.

\section{Stability analysis}

Stability of the 226 progenies for the 13 sugar-related traits were analysed by using PBSTAT online version 1.2. It calculates the coefficient of regression (bi), and mean $(\overline{\mathrm{X}})$ data of all progenies for each environment (Suwarno et al., 2008). Stability analysis was performed to identify stable genotypes for both environments.

\section{Results and Discussion}

\section{Statistical analysis}

The analysis of variance (ANOVA) for sugarrelated traits in 226 segregating progenies is presented in tables 2 and 3 . The pooled analysis of variance (mean squares) for environment, genotypes and genotypes $\times$ environment $(\mathrm{G} \times \mathrm{E})$ interaction were significant $(\mathrm{P}<0.01)$ for shoot counts, number of millable cane, stalk length, stalk diameter, stalk weight, internode length, internode number, number of green leaves, leaf length and HR Brix. Genotypes and genotypes $\times$ environment $(\mathrm{G} \times \mathrm{E})$ interaction were significant, while effect of environment was non-significant for cane yield $(\mathrm{Kg} / \mathrm{ha})$ (Tables 4 and 5).

\section{Population mean performance}

Population mean $(\overline{\mathrm{X}})$ of cane yield was 9.89 $\mathrm{Kg} /$ plot which ranged from 2.13 to 26.27
$\mathrm{Kg} /$ plot in both environments. Ninety five progenies had high CYLD over the population mean $(9.89 \mathrm{Kg} / \mathrm{plot})$. The range of population mean for SCNT, NMC and SL were recorded as 7 to 13,2 to 20 and 164.3 $\mathrm{cm}$ to $308.0 \mathrm{~cm}$, respectively. Other yield contributing traits viz., SD and SW, population mean ranged from $1.52 \mathrm{~cm}$ to 2.97 $\mathrm{cm}$ and $0.45 \mathrm{Kg}$ to $1.94 \mathrm{Kg}$ in both environments, respectively. The population mean value of HBR was recorded as $13.07 \%$, which ranged from $5.83 \%$ to $18.43 \%$ in both environments (Table 4).

\section{Stability}

Phenotypic stability among 226 progenies in terms of regression coefficient (bi) and population mean $(\overline{\mathrm{X}})$ were analysed to test their adoptability over two environments. According to Finlay and Wilkinson (1963), regression coefficient by regressing the mean of all genotypes on the environmental mean. Regression coefficients (bi) equal to 1.0 indicate average stability and is expected to be well adapted to all environments accompanied with high mean performance and low mean yield of genotypes are poorly adapted to all environments. Regression coefficient values above 1.0 have below average stability and are specially adapted to favourable environments. Regression coefficients below 1.0 provide an above average stability with expected to perform well under unfavorable environments.

\section{Cane yield}

A wide range of variation of regression coefficient was estimated as -103.76 to 142.7 for CYLD in 226 progenies. Out of 226 progenies, only three progenies exhibited regression coefficient values equal to 1.0 accompanied with lower mean values $(<9.89$ $\mathrm{Kg} / \mathrm{plot}$ ), which were poorly adapted to both environments. Regression coefficient of 110 
progenies were showed more than 1.0 with higher population mean of $9.89 \mathrm{Kg} / \mathrm{plot}$, which were adapted to favourable environments with average stability (Table 5 and Fig. 2).

\section{Number of millable cane}

The regression coefficients of the 226 segregating progenies ranged from -6.95 to 9.32. Thirty two progenies exhibited regression coefficient value closer to 1.0 for NMC accompanied with higher mean value of 9. It indicated that these progenies performed well under all tested environments for NMC. Regression coefficient value in twenty four progenies was equal to 1.0 with low mean value $(<9)$.

These genotypes were poorly adapted to both environments for NMC. Out of 226 genotypes, 91 genotypes showed regression coefficient (bi) value above one with average stability under favorable environments. 103 progenies had regression coefficient (bi) value below 1.0 and above average stability with expectation to perform well under unfavorable environments (Table 5 and Fig. 2).

\section{Stalk weight}

The regression coefficient ranged from 0.45 to 1.94 in 226 progenies. In stalk weight, 62 progenies were stable with regression coefficient equal to 1.0. Out of these, 28 progenies were stable with bi value of equal to 1.0 and high population means of $1.11 \mathrm{Kg}$, they were well adapted in all environments. Thirty four were poorly adapted to all environments with below mean value $(<1.11$ $\mathrm{Kg}$ ). Seventy four of 226 progenies were showed above 1.0 bi value, which were adapted in favourable environments with below average stability. In 90 progenies, bi value was recorded below 1.0, showed above average stability with expected to perform well under unfavorable environments (Table 5 and Fig. 2).

\section{Stalk length}

The regression coefficients ranged from -8.15 to 8.35 for SL. For stalk length 22 progenies showed regression values close to 1.0 and had higher mean length $(>251.2 \mathrm{~cm})$ and stable to both environments. Nine progenies were found equal to 1.0 bi value with low mean length $(<251.2 \mathrm{~cm})$. One hundred one progenies exhibited above 1.0 regression coefficient (bi) value and 94 progenies showed below 1.0 bi value (Table 5 and Fig. 2).

\section{Stalk diameter}

The range of regression coefficient of SD was -4.35 to 5.98 among 226 progenies. Forty three progenies were stable for stalk diameter with regression coefficient close to 1.0. Out of these, twenty six progenies showed bi value equal to 1.0 with high mean $(>2.22 \mathrm{~cm})$, stable genotype for all environments and rest (17) was poorly stable in both environments. Ninety progenies had regression values above 1.0 and hence exhibited average stability. The rest of 93 progenies showed their adaptability to unfavorable environments (Table 5 and Fig. 2).

\section{HR Brix}

Minimum variation of regression coefficient was recorded as -3.81 to 3.72 for HBR in 226 progenies. Out of 226 progenies, 70 progenies were found stable for HR Brix in both environments. HR Brix exhibited equal to 1.0 bi value in 47 progenies and they had found higher mean value (>13.97\%) over population mean. Therefore, making them highly stable to both environments. Twenty three were poorly adapted in both environments 
(Shahjahanpur and Muzaffarnagar). Ninety one progenies had regression values above 1 and hence exhibited below average stability in favourable environments (Table 5 and Fig. 2). Sixty five progenies showed their adaptability to unfavorable environments (Table 5).

The mean squares (MS) for genotypes and genotypes $\times$ environment $(\mathrm{G} \times \mathrm{E})$ interaction were significant $(\mathrm{P}<0.01)$ and environment was non-significant for cane yield $(\mathrm{Kg} / \mathrm{ha})$. This indicated the presence of genetic variability and varied response of the genotypes (progenies) to particular environments for CYLD only. The mean squares for other sugar-related traits viz., shoot counts, number of millable cane, stalk length, stalk diameter, stalk weight, internode length, internode number, number of green leaves, leaf length and HR Brix due to environment, genotypes and genotypes $x$ environment were significant which reflected the presence of variability among genotypes and differential response of genotypes (progenies) to various environments.

Fig.1 Development of mapping population derived from bi-parental cross of UP 9530 and Co 86011 at Shahjahanpur (1) and Muzaffarnagar location

(2) For genotype and environment interaction analysis

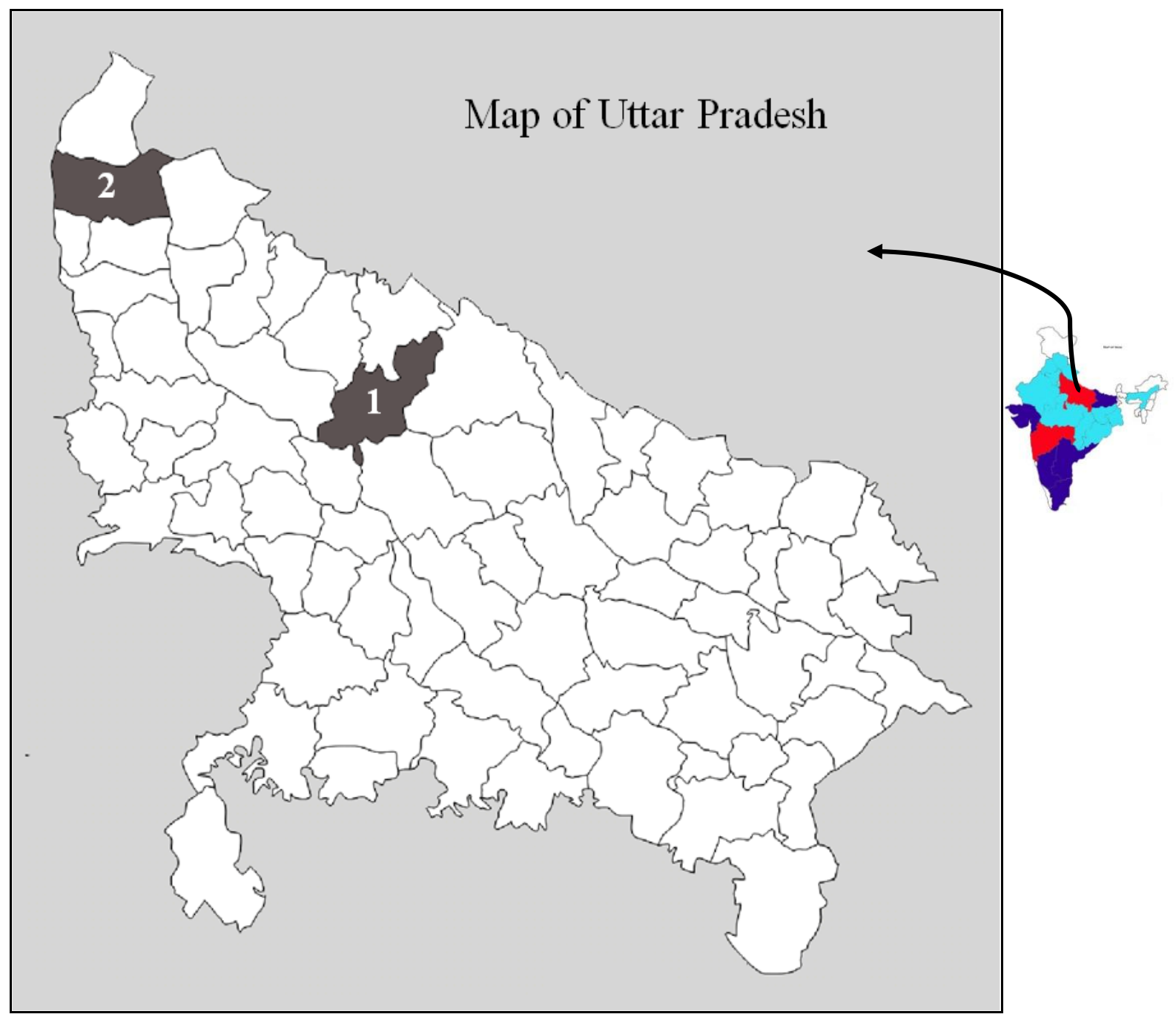


Fig.2 Two hundred twenty six segregating population means $(\overline{\mathrm{X}})$ vs. regression coefficients (bi) for sugar-related traits along with their grand mean over both environments

(Shahjahanpur and Muzaffarnagar)
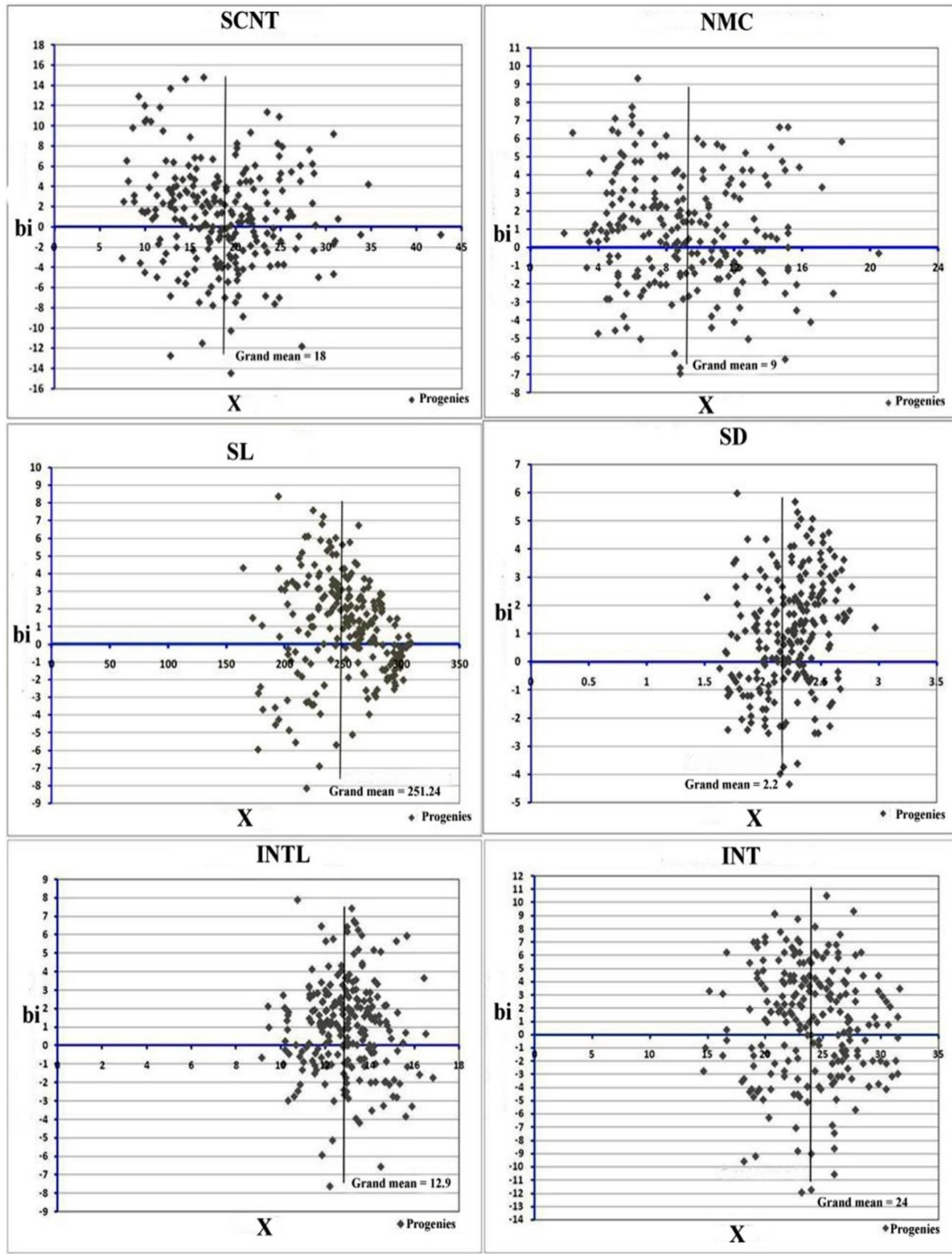


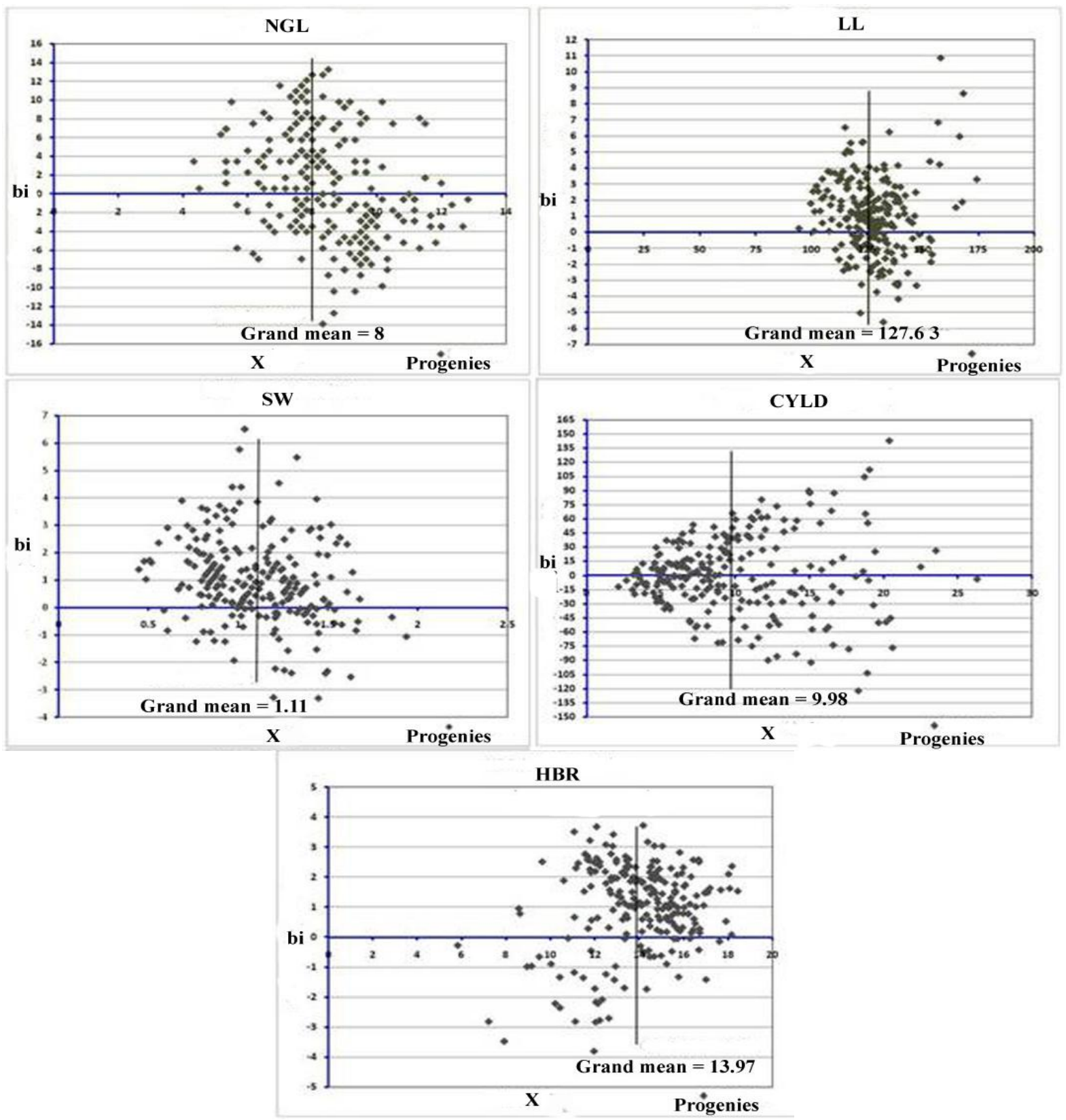

Table.1 Detail of environments

\begin{tabular}{|l|c|c|c|c|c|c|c|}
\hline \multirow{2}{*}{ Environment } & \multirow{2}{*}{$\begin{array}{c}\text { Planting } \\
\text { Date }\end{array}$} & Location & Latitude & Longitude & \begin{tabular}{c} 
Geographical location \\
range \\
\cline { 4 - 7 } Shahjahanpur
\end{tabular} & $\begin{array}{c}\text { Temp } \\
\text { humidity } \\
\text { range (\%) }\end{array}$ & $\begin{array}{c}\text { Soil } \\
\text { type }\end{array}$ \\
\hline Muzaffarnagar & $\begin{array}{c}22.02 .11 \\
(\text { Spring) }\end{array}$ & $\begin{array}{c}\text { Sugarcane } \\
\text { Research } \\
\text { Institute }\end{array}$ & $27^{\circ} 54^{\prime} \mathrm{N}$ & $\begin{array}{c}79^{\circ} 57^{\prime} \\
\mathrm{E}\end{array}$ & $4-42$ & $30.8-85.0$ & $\begin{array}{c}\text { Sandy } \\
\text { Loam }\end{array}$ \\
\hline (Spring) & $\begin{array}{c}\text { Research } \\
\text { Centre }\end{array}$ & $29^{\circ} 28^{\prime} \mathrm{N}$ & $\begin{array}{c}77^{\circ} 44^{\prime} \\
\mathrm{E}\end{array}$ & $3-39$ & $30.2-70.0$ & Sandy \\
\hline
\end{tabular}


Table.2 Pooled analysis of variance (ANOVA) for sum of square (SS) of sugar-related traits among 226 mapping population tested in two types of environments (Shahjahanpur and Muzaffarnagar)

\begin{tabular}{|c|c|c|c|c|c|c|c|c|c|c|c|c|}
\hline Source & DF & SCNT & NMC & SL & SD & SW & INT & INTL & NGL & $\mathbf{L L}$ & HBR & CYLD \\
\hline$G$ & 225 & $44295.23 *$ & $16688.84 *$ & $1407467.05^{*}$ & $97.96^{*}$ & $106.75^{*}$ & 17589.91* & $2752.69^{*}$ & $3625.62 *$ & $238734.34 *$ & 6010.26 & $30310.13^{*}$ \\
\hline Error & 900 & 9967.49* & $5027.68 *$ & $121596.90^{*}$ & $29.96^{*}$ & $18.91^{*}$ & $2157.25^{*}$ & $1133.01^{*}$ & $726.45^{*}$ & $74039.22 *$ & 1026.27 & $10182.81^{*}$ \\
\hline Total & 1355 & $95073.06^{*}$ & $37379.67 *$ & $2921058.71^{*}$ & $257.40^{*}$ & $179.59^{*}$ & 39199.24* & $7326.88 *$ & $7974.79 *$ & $562382.84 *$ & 20691.72 & 61738.54* \\
\hline
\end{tabular}

Probability $(\mathrm{P})$ level $<0.01, \mathrm{~ns}=$ Non-significant, $*=$ Significant

Table.3 ANOVA (mean of squares) for sugar-related traits among 226 segregating mapping population tested in Two types of environments (Shahjahanpur and Muzaffarnagar)

\begin{tabular}{|c|c|c|c|c|c|c|c|c|c|c|c|c|}
\hline Source & DF & SCNT & NMC & SL & SD & SW & INT & INTL & NGL & $\mathbf{L L}$ & HBR & CYLD \\
\hline $\bar{E}$ & 1 & $1556.95^{*}$ & $1510.15^{*}$ & $154496.07 *$ & $25.83^{*}$ & $15.34 *$ & $988.9^{*}$ & $457.20^{*}$ & $112.74^{*}$ & $38688.09^{*}$ & $4419.58^{*}$ & $12.70^{\mathrm{ns}}$ \\
\hline REP (within E) & 4 & $54.79 *$ & $22.25^{*}$ & $329.28 *$ & $0.14^{*}$ & $0.33 *$ & $21.85^{*}$ & $5.66^{*}$ & $12.72 *$ & $715.70 *$ & $6.41 *$ & $21.14^{\mathrm{ns}}$ \\
\hline $\mathrm{G}$ & 225 & $196.87 *$ & $74.17 *$ & $6255.41 *$ & $0.43^{*}$ & $0.47 *$ & $78.17 *$ & $12.23 *$ & $16.11 *$ & $1061.04 *$ & $26.712 *$ & $134.71 *$ \\
\hline $\mathrm{G} \times \mathrm{E}$ & 225 & $173.49 *$ & $62.51 *$ & $5494.14^{*}$ & $0.45^{*}$ & $0.17 *$ & $81.67 *$ & $13.16^{*}$ & $15.37 *$ & $924.70 *$ & $40.93 * *$ & $93.99 *$ \\
\hline Error & 900 & $11.08 *$ & $5.59 *$ & $135.11 *$ & $0.03 *$ & $0.02 *$ & $2.40 *$ & $1.25 *$ & $0.80 *$ & $82.27 *$ & $1.140^{*}$ & $11.31 *$ \\
\hline
\end{tabular}

$\mathrm{P}<0.01, \mathrm{~ns}=$ Non-significant, $*=$ Significant 
Table.4 Grand mean and ranges for important sugar-related traits in 226 segregating mapping population in two types of environments

\begin{tabular}{|c|c|c|c|c|c|c|c|}
\hline $\begin{array}{c}\text { Sl. } \\
\text { No. }\end{array}$ & Traits & $\mathbf{G}$ & $\mathbf{G} \times \mathbf{E}$ & $\begin{array}{c}\mathbf{C V} \\
\mathbf{( \% )}\end{array}$ & $\begin{array}{c}\text { Range of regression } \\
\text { coefficient }(\mathbf{b i})\end{array}$ & $\begin{array}{c}\text { Population } \\
\text { range } \\
(\mathbf{G} \times \mathbf{E})\end{array}$ & $\begin{array}{c}\text { Population } \\
\text { mean } \\
(\mathbf{G} \times \mathbf{E})\end{array}$ \\
\hline 1 & SCNT & $* *$ & $* *$ & 17.88 & $-12.75-14.78$ & $7-43$ & 18 \\
\hline 2 & NMC & $* *$ & $* *$ & 16.08 & $-6.95-9.32$ & $2-20$ & 9 \\
\hline 3 & SL & $* *$ & $* *$ & 4.63 & $-8.15-8.35$ & $164.3-308.0$ & 251.24 \\
\hline 4 & SD & $* *$ & $* *$ & 8.21 & $-4.35-5.98$ & $1.52-2.97$ & 2.22 \\
\hline 5 & SW & $* *$ & $* *$ & 13.07 & $0.45-1.94$ & $0.45-1.94$ & 1.11 \\
\hline 6 & INT & $* *$ & $* *$ & 6.46 & $-11.71-10.54$ & $15-32$ & 24.00 \\
\hline 7 & INTL & $* *$ & $* *$ & 8.7 & $-7.63-7.89$ & $9.15-16.82$ & 12.90 \\
\hline 8 & NGL & $* *$ & $* *$ & 10.55 & $-13.87-13.29$ & $4-13$ & 9.00 \\
\hline 9 & LL & $* *$ & $* *$ & 7.11 & $-5.62-10.86$ & $94.5-174.2$ & 127.63 \\
\hline 10 & CYLD & $* *$ & $* *$ & 34 & $-103.76-142.70$ & $2.13-26.27$ & 9.89 \\
\hline 11 & HBR\%-O & $* *$ & $* *$ & 7.64 & $-3.81-3.72$ & $5.83-18.43$ & 13.97 \\
\hline
\end{tabular}

$* *$ s significant at $\mathrm{P}<0.01$

Table.5 Regression coefficients (bi) greater than 1.0, less than 1.0 and equal to 1.0 with high and low mean for sugar-related traits cane among 226 progenies for stability analysis

\begin{tabular}{|c|c|c|c|c|c|c|c|c|c|c|}
\hline \multirow{3}{*}{$\begin{array}{c}\text { Sl. } \\
\text { No. }\end{array}$} & \multirow{3}{*}{ Traits } & \multicolumn{9}{|c|}{ Regression coefficient (bi) } \\
\hline & & \multirow[b]{2}{*}{$\begin{array}{c}= \\
1.0\end{array}$} & \multicolumn{2}{|c|}{ No. of progenies } & \multirow[b]{2}{*}{$<1.0$} & \multicolumn{2}{|c|}{ No. of progenies } & \multirow[b]{2}{*}{$>1.0$} & \multicolumn{2}{|c|}{ No. of progenies } \\
\hline & & & $\begin{array}{c}\text { High } \\
\text { mean }\end{array}$ & $\begin{array}{c}\text { Low } \\
\text { mean }\end{array}$ & & $\begin{array}{l}\text { High } \\
\text { mean }\end{array}$ & $\begin{array}{l}\text { Low } \\
\text { mean }\end{array}$ & & $\begin{array}{l}\text { High } \\
\text { mean }\end{array}$ & $\begin{array}{l}\text { Low } \\
\text { mean }\end{array}$ \\
\hline 1 & SCNT & 20 & 6 & 14 & 102 & 55 & 47 & 104 & 46 & 58 \\
\hline 2 & NMC & 32 & 8 & 24 & 103 & 61 & 42 & 91 & 51 & 40 \\
\hline 3 & SL & 31 & 22 & 9 & 94 & 60 & 34 & 101 & 40 & 61 \\
\hline 4 & SD & 43 & 26 & 17 & 93 & 36 & 57 & 90 & 63 & 27 \\
\hline 5 & SW & 62 & 28 & 34 & 90 & 54 & 36 & 74 & 28 & 46 \\
\hline 6 & INT & 18 & 11 & 7 & 97 & 59 & 38 & 111 & 51 & 60 \\
\hline 7 & INTL & 38 & 17 & 21 & 90 & 48 & 42 & 98 & 54 & 44 \\
\hline 8 & NGL & 14 & 3 & 11 & 107 & 73 & 34 & 105 & 29 & 76 \\
\hline 9 & LL & 50 & 21 & 29 & 90 & 51 & 39 & 86 & 37 & 49 \\
\hline 10 & CYLD & 3 & 0 & 3 & 113 & 49 & 64 & 110 & 46 & 64 \\
\hline 11 & HBR\%-O & 70 & 47 & 23 & 65 & 34 & 31 & 91 & 43 & 48 \\
\hline
\end{tabular}

Tahir et al., (2013, 2014) and Tiwari et al., (2011) reported that mean square for genotypes $\times$ environment were significant for quality traits. Jackson and Hogarth (1992) and Milligan (1994) found that genotypes $\times$ environment interaction were more important than the other interactions in Australia.

In present study, the stability analysis indicated the presence of significant $\mathrm{G} \times \mathrm{E}$ interactions for all the characters studied. Higher magnitude of mean squares due to environments indicates considerable differences between environments for all the characters and that these characters were greatly influenced by environments. The larger variation associated with environments indicated that the environments were diverse with large differences in their means. The significant $\mathrm{G} \times \mathrm{E}$ indicated differential and 
inconsistent responses of the genotypes across environments. Inconsistent genotypic responses to environmental factors such as temperature, sowing dates, soil moisture, soil type, or fertility level from location to location are a function of $\mathrm{G} \times \mathrm{E}$ interactions (Gilbert et al., 2006; Tiwari et al., 2011; Tahir et al., 2013, 2014). Generally, yield produced larger and significant $\mathrm{G} \times \mathrm{E}$ interaction, indicating the complexity of selecting for yield traits. Yields traits are known to be controlled by several quantitative genes that have small additive effects. A consistent yield of sugarcane crop is a need of sugarcane farmers under growing condition and gain higher yield (Kimbeng et al., 2009; Tiwari et al., 2011). These results were supported by Tahir et al., (2013, 2014). The effect of the environment is cumulatively high on yield traits due to small additive genes, resulting in complex $\mathrm{G} \times \mathrm{E}$ effects. Greater precision in testing and data analysis, including statistical methods suggested by Bull et al., (1992), Bissessur et al., (2000) and Kimbeng et al., (2002, 2009).

The large variation in regression coefficient among 226 segregating progenies was found for CYLD. The large variation indicates that different genotypes (progenies) had different environmental responses. A stable genotype is one that provides high mean value and consistent performance across the environments. The genotypes which were placed nearly to the origin with lower contribution to the magnitude of $\mathrm{G}$ and $\mathrm{E}$ interaction implying that the segregating genotypes were stable. The genotypes which were located distant from the origin were interactive genotypes contributing much to the increasing magnitude of genotype by environment interaction and cause unstable genotype performance. Rea and De Sousa (2002), Smith et al., (2005), Gilbert et al., (2006), Tiwari et al., (2011), Tahir et al., (2013, 2014) had also reported similar findings in their studies. The climate of Uttar Pradesh (Shahjahanpur and Muzaffarnagar) is the climate of North India which is the representative of subtropical part of India.

The stability analysis of HBR had performed significantly better than rest of the traits due more progenies has high mean value in both environments with regression near to unity. The magnitude of $G$ and $E$ interaction for quality traits (HBR) had less effect in comparison to other traits over testing locations, contributes to the stable performance of the genotypes. The vice-versa results for same trait were also found as unstable, which was influenced by environment. HBR was rarely influenced by the environment as compared to quantitative traits. Quality characters are genetically inherited rather than environment, and the same is reflected in the present study by the way of getting numerically significant regression coefficient for most of the progenies in comparison to other traits. This may be due to the differential adaptiveness and maturity time of the sugarcane genotypes. HBR is generally known to be more stable and can be measured with greater precision compared to CYLD. This finding is also reported by Jackson and McRae (2001), Kimbeng et al., (2002) and Tiwari et al., (2011). Therefore, HBR traits could not be improve through selection and requires further nobilization for quality improvement in sugarcane. At harvesting period, sugar content within the stalk occurs in higher concentration (Khan et al., 2013). The time of maturity for harvesting depends upon the genotype (varieties) and particular growing conditions (environment). Their interaction could be exploited for selection of elite variety within the particular environment. Gul et al., (2014) and Gedif et al., (2014) reported that the quality traits are sometimes influenced by environment because of time of maturity differs. 
The high variation in sugar yield-related traits revealed that the genotype is favourable to particular agronomic condition. Cane yield shows the large variation among 226 progenies due to $\mathrm{G} \times \mathrm{E}$ interaction. Out of 226 progenies, only 19 progenies are stable for sugar yield-related traits like SCNT, NMC, SL, SD, SW and HR Brix \% across two environments. Eight progenies are found stable for INT, INTL, NGL and LL across two environments. This study indicates that maximum progenies are influenced by $\mathrm{G} \times \mathrm{E}$ interactions and minimum genotypes are stable across both environments for all traits. It can be concluded that $\mathrm{G} \times \mathrm{E}$ interaction and stability testing could be beneficial for the selection of the elite genotype within the single environment as well across the environments, to achieve the higher cane yield along with improvement in other economic traits.

\section{References}

Aitken, K.S., P.A. Jackson and McIntyre, C.L. 2006. Quantitative trait loci identified for sugar related traits in a sugarcane (Saccharum spp.) cultivar $\times$ Saccharum officinarum population. Theoretical and Applied Genetics. 112:306-1317.

Anderson, D.L., H.G. de Boer and Portier, K.M. 1995. Identification of nutritional and environmental factors affecting sugarcane production in Barbados. Commun. Soil Sci. Plant Anal. 26:2887-2901.

Bissessur, D., R.A.E. Tilney-Bassett, L.C.Y. Lim Shin Chong, R. Domaingue and Julien, M.H.R. 2000. Family $\times$ environment and genotype $\times$ environment interactions for sugarcane across two contrasting marginal environments in Mauritius. Exp Agric. 36:101-114.

Bull J.K., D.M. Hogarth and Basford, K.E. 1992. Impact of genotype $\times$ environment interaction on response to selection in sugarcane. Australian Journal of Experimental Agriculture. 32: 731-737.
Finlay, R.W. and Wilkinson, G.N. 1963. The analysis of adaptiveness in a breeding programme. Australian Journal of Agriculture Research. 14:742-754.

Gedif, M., D. Yigzaw and Tsige, G. 2014. Genotype-environment interaction and correlation of some stability parameters of total starch yield in potato in Amhara region, Ethiopia. Journal of Plant Breeding and Crop Science. 6(3):21-40.

Gilbert, R.A., J.M.Jr. Shine, J.D. Miller, R.W. Rice and Rainbolt, C.R. 2006. The effect of genotype, environment, and time of harvest on sugarcane yields in Florida, USA. Field Crops Research. 95:156-170.

Gul, S., N.U. Khan, S. Batool, M.J. Baloch, M. Munir, M. Sajid, A.A. Khakwani, S.H. Ghaloo, Z.A. Soomro and Kazmi, S.F. 2014. Genotype by environment interaction and association of morphoyield variables in upland cotton. The Journal of Animal \& Plant Sciences. 24(1):262-271.

Hoarau, J.Y., B. Offman, A. D'Hont, A.M. Risterucci, D. Roques, J.C. Glaszmann and Grivet, L. 2001. Genetic dissection of a modern sugarcane cultivar (Saccharum spp.) I. Genome mapping with AFLP markers. Theoretical and Applied Genetics. 103:84-97.

Jackson, P. and McRae, T.A. 2001. Selection of sugarcane clones in small plots: Effects of plot size and selection criteria. Crop Science. 41:315-322.

Jackson, P.A. and Hogarth, D.M. 1992. Genotype $\mathrm{x}$ environment interactions in sugarcane. I. Patterns of response across sites and crop-years in North Queensland. Australian Journal of Agriculture Research. 43:1447-1459.

Kang, M.S. and Martin, F.A. 1987. A review of important aspects of GenotypeEnvironment Interactions and practical suggestions for sugarcane breeders. Journal American Society of Sugar Cane Technologists. 7:36.

Khan, I.A., A. Khatri, A.M. Javed, S.H. Siddiqui, M. Ahmad, N.A. Dahar, M. Khanzada, M. Hussain and Khan, R. 2002. Performance of promising sugarcane clone 
for yield and quality characters stability studies. Pakistan Journal of Botany. 34(3):247-251.

Khan, I.A., N. Seema, S. Raza, S. Yasmine and Bibi, S. 2013. Environmental interactions of sugarcane genotypes and yield stability analysis of sugarcane. Pakistan Journal of Botany. 45(5):1617-1622.

Kimbeng, C.A., A.R. Rattey and Hetherington, M. 2002. Interpretation and implications of genotype by environment interactions in advanced stage sugarcane selection trials in central Queensland. Australian Journal of Agricultural Research. 53:1035 - 1045.

Kimbeng, C.A., M.M. Zhou and da Silva, J.A. 2009. Genotype x environment interactions and resource allocation in sugarcane yield trials in the Rio Grande Valley Region of Texas. Journal of the American Society of Sugar Cane Technologists. 29:11-24

Magarey, R.C. and Mewing, C.M. 1994. Effect of sugarcane cultivars and environment on inoculum density of Pachymetra chaunorhiza in Queensland. Plant Disease. 78:1193-1196.

Petrovic, R., Stojnio and Ivanovic, M. 1988. Maturity and yield potential and yield stability in maize (Zea mays L.). Genetika. 20(3):269-279.

Ramburan, S., M. Zhou and Labuschagne, M. 2012. Integrating empirical and analytical approaches to investigate genotype $\times$ environment interactions in sugarcane. Crop Science. 52:2153-2165.

Ramon, R. and Orlando, D.S.V. 2002. Genotype $x$ environment interactions in sugarcane yield trials in the centra- western region of Venezuela. Inteciencia. 27(011):620-624.
Singh, R.K., S.P. Singh, D.K. Tiwari, S. Srivastva, S.B. Singh, M.L. Sharma, R. Singh, T. Mohapatra and Singh, N.K. 2013. Genetic mapping of sugar content and sugar yield related traits using ESTSSR markers in sugarcane (Saccharum spp.). Euphytica. 191:333-353.

Smith, A.B., B.R. Cullis and Thompson, R. 2005. The analysis of crop cultivar breeding and evaluation trials: An overview of current mixed model approaches. Journal of Agricultural Science. 143:449-462.

Suwarno, W.B., H. Sobir, Aswidinnoor and Syukur, M. 2008. PBSTAT: A web-based statistical analysis software for participatory plant breeding. 3rd International Conference on Mathematics and Statistics (ICoMS-3). Bogor Agriculture University, Indonesia. August 5-6.

Tahir, M., H. Rahman, A. Ali, S. Anwar and Khalid, M. 2013. Assessment of genotype $\mathrm{x}$ environment interaction and stability of promising sugarcane genotypes for different agronomic characters in Peshawar valley. American Journal of Experimental Agriculture. 3(1):142-151.

Tahir, M., I.H. Khalil, H. McCord Per and Glaz, B. 2014. Character association and selection indices in sugarcane. American Journal of Experimental Agriculture. 4(3):336-348.

Tiawari, D.K., P. Pandey, R.K. Singh, S.P. Singh and Singh, S.B. 2011. Genotype $\times$ environment interaction and stability analysis in elite clones of sugarcane (Saccharum officianarum L.). International Journal of Plant Breeding and Genetics. 5(1): 93-98.

\section{How to cite this article:}

Sujeet Pratap Singh, R.K. Singh, A. Nigam and Sharma, B.L. 2017. Genotype Environment Interaction for Sugar-Related Traits in Sugarcane Mapping Population. Int.J.Curr.Microbiol.App.Sci. 6(7): 4148-4159. doi: https://doi.org/10.20546/ijcmas.2017.607.430 